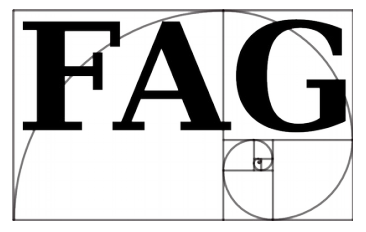

Filozoficzne Aspekty Genezy — 2014, t. 11

Philosophical Aspects of Origin

s. $205-240$

http://www.nauka-a-religia.uz.zgora.pl/images/FAG/2014.t.11/art.08.pdf

James Bradley

\title{
Losowość i natura Boga *
}

Dzisiejsza nauka odnotowuje liczne zjawiska, których natura wydaje się losowa. Jednakże wielu naturalistów, jak i teistów podziela przekonanie, że pojęcie losowości stoi w sprzeczności z treściq wiary chrześcijańskiej. Celem niniejszego artykulu jest wykazanie, że naukowa koncepcja losowości i tradycyjne chrześcijańskie ujęcie natury Boga sq wzajemnie zgodne. Co więcej, zostanie pokazane, że nie da się naukowo rozstrzygnać, czy w świecie przyrody losowość faktycznie występuje. Niemniej losowość zostanie zdefiniowana jako pojęcie matematyczne przydatne do wtaściwego interpretowania danych naukowych. Natomiast w myśl ujęcia powszechnie przyjmowanego przez teologów systematycznych natura Boga jest zgodna z obecnościa zjawisk losowych w przyrodzie.

\section{Zarys problemu}

Nauki przyrodnicze znają wiele zjawisk, których charakter wydaje się losowy. Naturaliści i teiści często jednak uważają, że pojęcie losowości jest niezgodne $\mathrm{z}$ tradycyjnym chrześcijańskim ujęciem natury Boga.

Niektórzy naturaliści akceptują pogląd, że w przyrodzie występują procesy przypadkowe, ale negują istnienie Boga. Na przykład twierdzą, że:

* James Bradley, „Randomness and God's Nature”, Perspectives on Science and Christian Faith 2012, vol. 64, no. 2, s. 75-89, http://www.asa3.org/ASA/PSCF/2012/PSCF6-12Bradley.pdf (11.10.2014). Za zgodą Autora i Redakcji z języka angielskiego przełożyli: Ewa Czyżowicz, Elżbieta Każmierska, Marek Krukowski, Grażyna Łęc, Iwona Macias, Hanna Nowicka, Małgorzata PiekŁo, Paulina Pietrzak i Dariusz Sagan. Przekładu dokonali studenci filozofii na Uniwersytecie Zielonogórskim w ramach translatorium z języka angielskiego, prowadzonego przez dra Dariusza Sagana. 
Im bardziej rozumiemy sposób funkcjonowania przyrody, tym bardziej zdajemy sobie sprawę, że siły natury kształtowane są przez ślepy, bezcelowy przypadek. Choćbyśmy przemierzyli Wszechświat wzdłuż i wszerz, pokonując miliardy lat świetlnych, choćbyśmy zagłębili się w krainę subjądrowych cząstek, a następnie wznieśli się ponad galaktyki, zderzające się ze sobą niczym gigantyczne czynele, to nigdzie nie dojrzymy ani śladu celu, ani śladu planu. ${ }^{1}$

Z drugiej strony część teologów uznaje, że istnienie Boga wyklucza możliwość przypadku. R.C. Sproul pisze:

Już samo istnienie przypadku wystarczyłoby, aby strącić Boga z jego kosmicznego tronu. Przypadek nie musiałby rządzić przyrodą, nie musiałby być zasadą najwyższą. Nawet gdyby istniał jedynie jako bezsilny, pokorny sługa, to Bóg stałby się nie tylko nieistotnym reliktem przeszłości, ale i nie miałby nic do zrobienia. Gdyby przypadek istniał choćby w swej najsłabszej możliwej postaci, Bóg byłby skończony. ${ }^{2}$

W tym artykule wykażę, że naukowe pojęcie losowości i tradycyjne chrześcijańskie rozumienie natury Boga nie wykluczają się. Nie udowodnię, że losowość z całą pewnością istnieje - wręcz przeciwnie, będę argumentował, że jej istnienia nie da się ustalić metodami naukowymi. Niemniej postaram się uzasadnić, że koncepcja losowości zapewnia wiarygodną interpretację danych naukowych i że losowość jest spójna z Boskimi przymiotami.

Plan artykułu jest następujący. W Części 2 przyjrzę się wzorcom losowości $\mathrm{z}$ różnych dziedzin. Dzięki temu przedstawiona w dalszej części filozoficzna i teologiczna dyskusja nad losowością zostanie umieszczona w kontekście ustaleń teorii prawdopodobieństwa, statystyki i nauk przyrodniczych. W Części 3 przeanalizuję koncepcje losowości wywiedzione z tych wzorców oraz zaprezentuję dwie interpretacje modeli indeterministycznych — instrumentalizm i realizm. Uważam, że wybór między tymi interpretacjami wyłącznie na gruncie nauki jest niemożliwy i dlatego rozważania nad losowością muszą mieć również charakter metafizyczny lub teologiczny. W Części 4 wyjaśnię, dlaczego losowość można słusznie uznać za kluczową cechę świata fizycznego. W Części

\footnotetext{
${ }^{1}$ David Stover and Erika Erdmann, A Mind for Tomorrow: Facts, Values, and the Future, Praeger Publishers, Westport, Connecticut 2000, s. 37.

${ }^{2}$ R.C. Sproul, Not a Chance: The Myth of Chance in Modern Science and Cosmology, Baker Books, Grand Rapids, Michigan 1994, s. 3.
} 
5 zaprezentuję klasyczne ujęcie atrybutów Boga z perspektywy teologii systematycznej. Będę argumentował, że większość Boskich przymiotów nie wyklucza się z rzeczywistym istnieniem losowości. Niemniej cztery kwestie - celowość, kontrola, przedwiedza i przyczynowość - stanowią potencjalne źródło konfliktu. W Częściach 6-9 zamierzam pokazać, że taki konflikt jest jedynie pozorny. W Części 10 wythumaczę, jak realistyczna interpretacja losowości może wpłynąć na rozumienie relacyjnych atrybutów Boga.

\section{Wzorce losowości}

Losowość potocznie rozumie się jako coś, co nie jest wynikiem projektu, czego nie można ująć metodycznie, co nie ma celu, uporządkowania ani przyczyny. Jednak w matematyce, statystyce czy w naukach przyrodniczych losowość pojmuje się inaczej. W Strukturze rewolucji naukowych Thomas Kuhn wykorzystał pojęcie wzorca. ${ }^{*}$ Wzorcami były dla niego te przykłady stosowane w nauczaniu danej dyscypliny, które pozwalają przekazywać jej kluczowe koncepcje z pokolenia na pokolenie:

Mam na myśli przede wszystkim konkretne rozwiązania problemów, z jakimi studenci stykają się od początku swojego kształcenia naukowego, czy to w laboratoriach, czy to na egzaminach, czy to na końcu rozdziałów w podręcznikach. [...] Na przykład wszyscy fizycy zaczynają od poznawania tych samych wzorów: problemów takich, jak równia pochyła, wahadło stożkowe i orbity Keplera; przyrządów takich jak wernier, kalorymetr, mostek Wheatstone'a. ${ }^{3}$

Przedstawię teraz dziewięć wzorców losowości, które uzmysłowią nam, jak termin ten funkcjonuje w matematyce, statystyce i naukach przyrodniczych.

\footnotetext{
* (Przyp. tłum.) Ściśle biorąc, w polskim przekładzie użyto terminu „wzór” jako odpowiednika angielskiego słowa „exemplar”. Termin ten zbyt mocno może sugerować, że chodzi o wzory matematyczne, tymczasem Kuhn ma na myśli szerszą kategorię — coś w rodzaju wzorcowych przykładów czy wzorcowych rozwiązań. $Z$ tego względu, zwłaszcza w kontekście niniejszego artykułu, najlepiej posługiwać się więc terminem „wzorzec”.

${ }^{3}$ Jest to cytat z Postscriptum do drugiego wydania książki: Thomas S. KuHn, Struktura rewolucji naukowych, przeł. Helena Ostromęcka i Justyna Nowotniak, Fundacja Aletheia, Warszawa 2001, s. 322-323.
} 
W dalszej części artykułu wykorzystam te wzorce do zilustrowania kluczowych zagadnień.

\section{Wzorzec 1: Gry losowe}

„Gry losowe” to między innymi gra w karty, w kości, rzuty monetą czy ruletka. Studenci często właśnie na takich przykładach uczą się podstaw rachunku prawdopodobieństwa. ${ }^{4} \mathrm{~W}$ podręcznikowych omówieniach tych gier wprowadza się wiele różnych pojęć. W każdej takiej grze mamy do czynienia z niewielką, skończoną ilością wyników o identycznym prawdopodobieństwie. W wypadku rzutów monetą wskazuje się, że jeśli moneta jest „uczciwa”, to wyniki są równie prawdopodobne. Ponieważ suma prawdopodobieństw wszystkich możliwych wyników musi wynosić dokładnie jeden, więc prawdopodobieństwo wypadnięcia orła bądź reszki równe jest $1 / 2$. Założenie uczciwości wyznacza z kolei konkretną metodę obliczania prawdopodobieństw. Omawiana jest również częstościowa interpretacja prawdopodobieństwa, zgodnie z którą prawdopodobieństwo $1 / 2$ należy ujmować w kategoriach prawa wielkich liczb, ${ }^{5} \mathrm{w}$ świetle którego przy dużej ilości rzutów względna częstość każdego wyniku zbliża się do 1/2. Podrzucona moneta może wylądować na krawędzi lub wpaść do studzienki kanalizacyjnej. Założenie, że są tylko dwa wyniki (orzeł i reszka), wskazuje, że reprezentacje probabilistyczne są modelami, czyli uproszczeniami lub idealizacjami bardziej złożonej rzeczywistości.

\section{Wzorzec 2: Liczby pseudolosowe}

Gry lub symulacje komputerowe często polegają na zastosowaniu liczb pseudolosowych. Liczby te są generowane przez algorytm, lecz wydają się loso-

\footnotetext{
${ }^{4}$ Współczesną koncepcję prawdopodobieństwa sformułował Andriej Nikołajewicz Kołmogorow w latach trzydziestych dwudziestego wieku. Pierwsze powszechnie używane podręczniki zostały napisane w 1950 roku przez Williama Fellera w Stanach Zjednoczonych i Borysa Gnedenkę w Związku Radzieckim. O wszystkich wymienionych tu przykładach gier losowych, a także o innych, Feller pisze w Rozdziale 1. Gnedenko jako swoje główne przykłady wybrał gry w kości i w karty.

${ }^{5} \mathrm{~W}$ interpretacji bayesowskiej prawdopodobieństwa wyrażają subiektywne stopnie przekonania.
} 
we w tym sensie, że o ile algorytm działa prawidłowo, mają one jednakowy rozkład w danym zakresie (na przykład od 0 do 1). Dzięki temu w grach i symulacjach uzyskuje się coś w rodzaju „uczciwości”. Zwykle punktem wyjściowym $\mathrm{w}$ takich algorytmach jest wybór pewnej liczby (zwanej ziarnem). Zostaje ona wprowadzona do wzoru, na podstawie którego generowana jest kolejna liczba stanowiąca ziarno dla następnej i tak dalej. Gdyby znane były: wartość pierwszego ziarna oraz wzór, można by obliczyć wszystkie liczby. Jednak ziarno jest często wybierane w ten sposób, aby w praktyce liczby były nieprzewidywalne. Na przykład dobiera się cyfry z czasu odliczanego przez zegar komputera w chwili żądania wyboru liczby. Niemniej John von Neumann zażartował kiedyś: „To oczywiste, że każdy, kto sądzi [że] metody arytmetyczne pozwalają generować losowe cyfry, popełnia grzech". ${ }^{6}$

\section{Wzorzec 3: Próbkowanie losowe}

Stanowi ono podstawę badań statystycznych. Zwykle polega to na numerowaniu członków populacji i komputerowym lub tabelarycznym generowaniu liczb pseudolosowych, które służą do wyboru próby populacji. Statystycy uważają, że próbkowanie losowe jest metodą, która daje największe szanse na uzyskanie bezstronnych, czyli reprezentatywnych prób populacji. Metoda ta jest tak powszechna, że stanowi szczególnie znany przykład zastosowania losowości do osiągnięcia określonego celu.

\section{Wzorzec 4: Rozpad promieniotwórczy}

Jako przykład rozważmy próbkę węgla-14. Stopniowo, poprzez emisję cząstek beta - elektronów lub pozytonów - atomy węgla w tej próbce ulegają rozpadowi, tworząc azot-14. Tempo emisji jest stałe, dzięki czemu można obliczyć okres połowicznego rozpadu, czyli czas potrzebny do rozpadu połowy radioaktywnego materiału w próbce. $\mathrm{W}$ przypadku węgla-14 okres połowicznego rozpadu wynosi $5,730 \pm 40$ lat. Nie potrafimy jednak — przynajmniej przy dzisiejszym stanie wiedzy — przewidzieć, w którym momencie jakiś poszczególny

\footnotetext{
${ }^{6}$ John von Neumann, „Various Techniques Used in Connection with Random Digits”, $A p$ plied Mathematics Series 1951, no. 12, s. 36.
} 
atom w próbce wyemituje taką cząstkę. Czas emisji stanowi więc wzorzec ciągłej zmiennej losowej (w odróżnieniu od nieciągłych zmiennych losowych omówionych w trzech poprzednich przykładach). Niezdolność do wskazania deterministycznego procesu, który umożliwiałby przewidywanie momentu emisji poszczególnych cząstek, często nie jest traktowana jako tymczasowy stan naszej niewiedzy, lecz uznawana za przesłankę na rzecz poglądu, że podstawowe procesy fizyczne naprawdę mogą mieć charakter indeterministyczny.

\section{Wzorzec 5: Procesy Poissona}

Zdarzenia, w których istotne znaczenie ma czas, takie jak podchodzenie klientów do sklepowej kasy, docieranie promieni kosmicznych do detektora lub zgłoszeń do centrum telefonicznego, modelowane są często za pomocą procesów Poissona. W takich procesach zdarzenia następują losowo w stałym tempie w określonym interwale czasu i mają równe prawdopodobieństwo nastąpienia $\mathrm{w}$ dowolnym momencie w tym interwale. Te założenia gwarantują, że okres następowania kolejnych zdarzeń będzie odpowiadał wzorcowi wykładniczemu. Jeśli częstość zdarzeń w ustalonym interwale czasu obliczona zostanie dla wielu takich interwałów (w których występuje to samo tempo zdarzeń), to częstości będą odpowiadać wzorcowi znanemu jako rozkład Poissona. Procesy Poissona ilustrują fakt, że losowość może być wynikiem kumulacji zdarzeń, które indywidualnie nie są losowe - koincydencja dużej liczby niezależnych zdarzeń, z których każde determinowane jest przez swoje własne (zapewne deterministyczne) przyczyny, prowadzi do zachowania zgodnego z założeniem losowości.

\section{Wzorzec 6: Nieoznaczoność kwantowa}

Nie możemy widzieć elektronów, ale potrafimy tworzyć ich matematyczne reprezentacje. „Spin” to własność elektronów, mimo że (o ile wiemy) elektrony nie rotują w tym samym sensie, co duże obiekty, jak piłki bejsbolowe czy planety. Spin elektronu może znajdować się w jednym $\mathrm{z}$ dwu stanów: spin do góry lub spin do dołu. Nie znaczy to jednak, że elektrony istnieją w jednym z tych stanów, lecz że są reprezentowane matematycznie jako rozkład prawdopodobieństwa po możliwych stanach spinu (a także innych własnościach). Kiedy jednak elektrony przechodzą przez urządzenie zwane rozdzielaczem wiązki, nastę- 
puje modulacja (zwana kolapsem funkcji falowej), taka że tor elektronu wskazuje, iż elektron znajduje się albo w stanie spinu do góry, albo spinu do dołu, a każdy z tych stanów ma prawdopodobieństwo $1 / 2$. Zgodnie z kopenhaska interpretacja $^{7}$ tego zjawiska charakter kolapsu jest taki, na jaki wygląda — czyli indeterministyczny. Interpretację tę akceptuje większość fizyków i jest ona powszechnie nauczana. Natomiast w interpretacji Bohmowskiej ${ }^{8}$ kolapsowi przypisuje się charakter deterministyczny i zależność od istnienia dotychczas niepoznanych ukrytych zmiennych. Nadzieja na odnalezienie takich zmiennych w wielkim stopniu jednak zmalała w roku 1964 wraz z ogłoszeniem twierdzenia Bella. Dzięki niemu można empirycznie sprawdzić, czy nieoznaczoność kwantową da się wyjaśnić lokalnymi ukrytymi zmiennymi (czyli takimi, które zgodne są z założeniem, że prędkość światła ma największą wartość z możliwych w przyrodzie). Przeprowadzone testy temu zaprzeczyły. ${ }^{9}$ Niemniej problem, jak interpretować kolaps funkcji falowej, jest daleki od ostatecznego rozwiązania. Dwie inne interpretacje to hipoteza dekoherencji, skupiająca się na oddziaływaniu elektronu z jego środowiskiem, oraz hipoteza wieloświata. W myśl tej ostatniej kolaps jest deterministyczny — reprezentacja elektronu jako fali ma charakter realny, ale neguje się realność jej kolapsu. Rzeczywistość przedstawiana jest jako bogato rozgałęzione drzewo, gdzie wszystkie możliwe alternatywne historie elektronu i wszystkie możliwe przyszłe stany są realne.

\section{Wzorzec 7: Groch Mendla}

Gregor Mendel (1822-1884), austriacki mnich augustiański, znany jest jako „ojciec współczesnej genetyki”. Badając groch rosnący w klasztornym ogrodzie, w którym robił eksperymenty, odkrył prawa dziedziczenia, które rządzą przekazywaniem cech z rodziców na dzieci. Na przykład dana cecha grochu (kolor, struktura $\mathrm{i}$ tak dalej) występuje $\mathrm{w}$ dwóch genetycznych postaciach (lub alle-

\footnotetext{
${ }^{7}$ Opracowaną przez Nielsa Bohra i Wernera Heisenberga w latach 1924-1927.

${ }^{8}$ Wyartykułowanej przez Louisa de Broglie w 1927 roku i na nowo odkrytej przez Davida Bohma w 1952.

${ }^{9}$ Nancey Murphy argumentuje, że Bóg jest taką nielokalną zmienną (por. Nancey MuRPHY, „Divine Action in the Natural Order: Buridan's Ass and Schrödinger's Cat”, w: Robert John Russell, Nancey Murphy, and Arthur R. Peacocke (eds.), Chaos and Complexity: Scientific Perspectives on Divine Action, 2nd ed., Vatican Observatory Publications, Rome 2000, s. 325-358.
} 
lach), które można oznaczyć jako „A” dla formy dominującej i „a” dla formy recesywnej. Genotypy kierujące ekspresją takiej cechy występują w parach AA, Aa lub aa. Na podstawie starannie zebranych danych Mendel wykazał, że potomstwo hybryd (posiadających formę Aa) pojawia się losowo w stosunku 1/4 dla formy AA, $1 / 2$ dla Aa i $1 / 4$ dla aa. Praca Mendla wyprzedziła odkrycie genów, ale późniejsze ich odkrycie umożliwiło zrozumienie mechanizmów leżących u podłoża praw Mendla. Losowe przekazywanie informacji genetycznej potomstwu to kluczowy element teoretycznego szkieletu współczesnej teorii ewolucji.

\section{Wzorzec 8: Dyfuzja}

Rozważmy komórkę w ludzkim ciele. Potrzebuje ona składników odżywczych i tlenu dostarczanego jej z zewnątrz, a w swoim wnętrzu gromadzi odpady, które musi usunąć. Przez półprzepuszczalną błonę komórkową przedostaje się woda, zabierając ze sobą rozpuszczone substancje i równoważąc ich koncentrację po obu stronach błony. Proces ten nazywany jest osmoza i stanowi formę $d y f u z j i$, czyli losowego przemieszczania się cząsteczek z obszarów o wyższej koncentracji do obszarów o koncentracji niższej. Za ten losowy ruch odpowiada energia cieplna cząsteczek, z których każda porusza się niezależnie, a taki ruch zachodzi nieustannie we wszystkich cieczach i gazach. Znane nam życie nie mogłoby istnieć bez osmozy.

\section{Wzorzec 9: Teoria chaosu}

„Chaos” to popularne określenie deterministycznej nieokresowości. ${ }^{10} \mathrm{Ce}-$ chuje on układy nieliniowe, takie jak globalne ciśnienie atmosferyczne. Takie układy są nadzwyczaj wrażliwe na warunki początkowe. Są one deterministyczne w tym sensie, że gdyby dokładnie znano rządzące nimi równania oraz stan wyjściowy, to dałoby się przewidzieć całe ich przyszłe zachowanie. Ich stanu wyjściowego nie da się jednak zmierzyć w pełni precyzyjnie. Ponadto, układ wzmacnia maleńkie zmiany stanu wyjściowego, tak że dwa układy, które początkowo są ze sobą blisko związane, $\mathrm{z}$ upływem czasu stają się w coraz więk-

\footnotetext{
${ }^{10}$ Nazwę tę spopularyzował James Gleıck, Chaos. Narodziny nowej nauki, przeł. Piotr Jaśkowski, Wydawnictwo Zysk i S-ka, Poznań 1996.
} 
szym stopniu odrębne. Dlatego przyszłe stany są w praktyce nieprzewidywalne, mimo że są przewidywalne w zasadzie. Układy te są deterministyczne, ale ich długoterminowe zachowanie wydaje się losowe.

\section{Losowość}

Popularna koncepcja losowości, o której wspomniano wcześniej — coś, co nie jest wynikiem projektu, czego nie można ująć metodycznie, co nie ma celu, uporządkowania ani przyczyny - jest myląca. Na przykład przy rzucie uczciwą kostką mamy sześć możliwych wyników, a każdy wynik ma prawdopodobieństwo 1/6. Tak naukowcy, jak laicy postrzegają takie wyniki jako losowe, ale kostka jest starannie i celowo zaprojektowana, charakteryzuje się uporządkowaniem i ewidentnie ma (zapewne indeterministyczną) przyczynę.

Niemniej nawet specjaliści nie dysponują powszechnie przyjmowaną, jednoznaczną definicją terminu „losowy”. Dziewięć omówionych powyżej wzorców dotyczy procesów nieokreślonych — mających wiele możliwych wyników, których nie da się jednoznacznie przewidzieć. Termin „nieokreślony” jest jednak wieloznaczny. Fizycy, na przykład, często mówią o losowości, umieszczając ją w kontekście przyczynowości lub jej braku. Tak więc wynik jest określony, jeśli jest „zdeterminowany”, to jest ma przyczynę. Nieokreślony jest wówczas, gdy nie ma przyczyny. Natomiast matematycy i statystycy zwykle unikają kwestii przyczynowości i skupiają się na nieprzewidywalności.

Termin „losowy” może też odnosić się zarówno do wyników, jak i procesów. ${ }^{11}$ Wyidealizowany proces (zakładający doskonałą powtarzalność) może wygenerować dowolnie długi ciąg wyników. Algorytmiczna teoria informacji (ATI) bada nieskończone ciągi bitów, dostarczając matematyczny model sekwencji wyników. ATI wprowadza różne koncepcje losowości. Na przykład w przypadku losowości Martina-Löfa ciąg bitów jest losowy, jeśli przechodzi wszystkie sensowne testy statystyczne na losowość. W innym ujęciu mówi się o niekompresowalności - ciąg jest kompresowalny, jeżeli można go opisać cią-

\footnotetext{
${ }^{11} \mathrm{~W}$ artykule Antony'ego Eagle'a na temat przypadku, zamieszczonym w Stanford Encyclopedia of Philosophy, termin przypadek odniesiony jest do procesów, a losowy do danych.
} 
giem od niego krótszym. ${ }^{12}$ Ciągi losowe są niekompresowalne. Koncepcje te doprowadziły do ogromnych sukcesów, na przykład do opracowania metody decydowania, czy jeden ciąg jest $\mathrm{w}$ większym stopniu losowy od drugiego. Za wszystkimi sformułowaniami losowości w ramach ATI kryje się intuicja, że ciągi losowe nie mają rozpoznawalnego wzorca. Jednocześnie ATI precyzyjnie definiuje pojęcie „braku wzorca”, nadając mu znaczenie nieobliczalności - nie istnieje algorytm, który na podstawie pierwszych $\mathrm{n}$ bitów losowego ciągu byłby W stanie obliczyć bit $(\mathrm{n}+1){ }^{13}$

Definicja mówiąca o procesie (w kategoriach nieprzewidywalności) oraz definicja odnosząca się do produktu (brak wzorca w zestawieniu wyników) są podobne, lecz nie równoważne - nieskończony ciąg bitów, któremu brakuje wzorca, reprezentuje wiele wyników i jego składowe są nieprzewidywalne. Jednakże rzeczywiste procesy nigdy nie są doskonale powtarzalne i nie mogą generować nieskończonej sekwencji wyników. Ponadto, wyniki procesów naprawdę mogą być nieprzewidywalne, ale dla każdego skończonego zbioru wyników istnieje niezerowe prawdopodobieństwo, że taki zbiór zawiera rozpoznawalny wzorzec. ATI oferuje też kilka nierównoważnych definicji. Tak więc losowość można postrzegać jako zbiór koncepcji, które cechują się ,podobieństwem rodzinnym" łączącym pojęcia wielu wyników, nieprzewidywalności, braku wzorca w wyidealizowanej sekwencji wyników. Mówiąc o tej rodzinie, będę po prostu używał słów „nieokreśloność” i „nieokreślony”. Powinno to wystarczyć do zachowania spójności mojej argumentacji.

Ciągiem epistemicznie losowym jest taki, który wydaje się losowy, lecz w rzeczywistości posiada wzorzec możliwy do obliczenia za pomocą algorytmu. Dla ciągu ontologicznie losowego nie istnieje algorytm, który mógłby obliczyć jego składowe. Są to zatem dwa bardzo odmienne typy losowości. Losowość ontologiczna (o ile istnieje w świecie przyrody) stanowi cechę samej natury rzeczy, zaś losowość epistemiczna to losowość pozorna — jest to funkcja ludzkiej

\footnotetext{
${ }^{12}$ Przykładowo ciąg $010101010 \ldots$ może mieć skończony opis jako nieskończone powtarzanie 01 , mimo że sam ciąg jest nieskończony.

${ }^{13}$ ATI eliminuje wszelkie pozostałe wieloznaczności z idei obliczalności, definiując ją za pomocą maszyn Turinga stanowiących abstrakcyjny model obliczeniowy, który pełni rolę teoretycznej podstawy informatyki.
} 
percepcji rzeczy, ale nie ich natury. ${ }^{14}$ Determinizm to stanowisko filozoficzne, zgodnie z którym losowość ontologiczna nie istnieje w świecie fizycznym, a indeterminizm utrzymuje tezę wprost przeciwną. Istnieją dwie główne interpretacje modeli, których elementem jest losowość. Zgodnie z instrumentalizmem losowość to użyteczne narzędzie, gdy nasza wiedza jest ograniczona, natomiast według realizmu odpowiada ona głębszej, indeterministycznej rzeczywistości.

Niektórzy myśliciele chrześcijańscy opowiadali się za realistyczną interpretacją losowości, a inni przeciwko niej. John Byl odrzuca losowość ontologiczną w fizyce, argumentując, że preferencja dla indeterministycznych interpretacji mechaniki kwantowej ,[...] motywowana jest w dużej mierze preferencjami filozoficznymi i teologicznymi”. ${ }^{15}$ Cytowany wcześniej R.C. Sproul także przeczy realnemu charakterowi losowości. Niels Gregersen uznaje, że wszystkie prawa przyrody, łącznie z tymi, które dotyczą losowości, są wzorcami nakładanymi na przyrodę przez ludzi. Według niego:

[...] prawa przyrody to po prostu odpowiednio dobrane prawidłowości przyrodnicze, o ile można je zidentyfikować na podstawie badań empirycznych. W tym ujęciu prawa przyrody są metaforami lub skrótami ogólnych opisów prawidłowości. Założenia ontologiczne są tu niepotrzebne. ${ }^{16}$

Inni autorzy chrześcijańscy argumentują, że nieokreśloność dostrzegana w ramach mechaniki kwantowej wskazuje na bardziej fundamentalną nieokreśloną rzeczywistość. John Polkinghorne uzasadnia to rozumowanie na gruncie krytycznego realizmu - jak sam go nazywa. Jego punktem wyjścia jest realizm, czyli idea, że rzeczy są takie, na jakie wyglądają, zaś krytyczny realizm przy-

\footnotetext{
${ }^{14}$ Losowość ontologiczna, zdefiniowana $\mathrm{w}$ ten sposób, nie dotyczy wyłącznie ograniczeń ludzkiej wiedzy. Jeśli nie ma algorytmu mogącego obliczyć jakiś wzorzec, to Bóg również nie może go obliczyć. Można sobie oczywiście wyobrazić, że Bóg może znać listę wyników w jakiś inny sposób, na przykład dzięki posiadaniu bezczasowej wiedzy, która obejmuje wszystkie przeszłe, teraźniejsze i przyszłe wyniki danego procesu. Czy taka wiedza może istnieć, jest sprawą sporną. Powrócę do tego zagadnienia w Części 8.

${ }^{15}$ John ByL, „Indeterminacy, Divine Action and Human Freedom”, Science and Christian Belief 2003, vol. 15, no. 2, s. 106.

${ }^{16}$ Niels Henrik Gregersen, „Laws of Physics, Principles of Self-Organization, and Natural Capacities: On Explaining a Self-Organizing World”, w: Fraser WatTs (ed.), Creation: Law and Probability, Fortress Press, Minneapolis, Minnesota 2009, s. 81.
} 
znaje, że nasza percepcja może zostać zwiedziona, na przykład przez złudzenia optyczne. Stanowisko to uznaje też, że rzeczy bardzo małe (na poziomie kwantowym) i rzeczy bardzo duże (na poziomie galaktycznym) wykraczają poza sferę naszego zwykłego doświadczenia. A więc mimo że realizm jest zasadniczo słuszny, musimy zachować ostrożność. Polkinghorne opowiada się za interpretacją kopenhaską, wskazując, że kiedy coś takiego jak nieoznaczoność kwantowa było badane przez wielu ludzi na przestrzeni wielu lat i przy tym uzyskiwano bardzo przekonujące i spójne wyniki, to przejście od tezy, że , $x$ wygląda na takie", do tezy, że „,x jest takie", należy uznać za uzasadnione. ${ }^{17}$

Keith Ward przekonuje, że prawa indeterministyczne zostawiają miejsce dla swobodnej aktywności twórczej. ${ }^{18}$ David Bartholomew uważa, że Bóg posługuje się przypadkiem. ${ }^{19}$ Swojej książce nadał podtytuł: „Czy Bóg może mieć jedno i drugie?”, odnosząc się do istnienia zarówno losowości, jak i uporządkowania, i jego odpowiedź jest twierdząca.

Twierdzę, że rozstrzygnięcie, wyłącznie na gruncie nauki, czy losowość ontologiczna istnieje, nie jest możliwe (chociaż w następnej części będę argumentował, że świadectwa na jej rzecz są silniejsze niż przeciwko niej). Rozstrzygnięcie tej kwestii wymagałoby kompletnej wiedzy o Wszechświecie. Aby to zrozumieć, przypuśćmy, że Profesor A jest indeterministą. Rozważmy dowolny konkretny przykład czegoś, co uważa on za zjawisko indeterministyczne. Profesor A nigdy nie może wykluczyć możliwości, że jakieś przyszłe odkrycie każe uznać to zjawisko za deterministyczne. Przypuśćmy teraz, że Profesor B jest deterministą. Przy braku kompletnej wiedzy o Wszechświecie nigdy nie może on wykazać, że uda się znaleźć przyczyny deterministyczne dla wszystkich zjawisk fizycznych. Prawdziwości żadnego z tych stanowisk nie da się zatem udowodnić naukowo. Jeśli chcemy zgłębić pojęcie losowości, niezbędne są rozważania

\footnotetext{
${ }^{17}$ Por. John Polkinghorne, „The Metaphysics of Divine Action”, w: Robert John Russell, Nancey Murphy, and Arthur R. Peacocke (eds.), Chaos and Complexity: Scientific Perspectives on Divine Action, The Center for Theology and the Natural Sciences, Berkeley, California 1996.

${ }^{18}$ Por. Keith WARD, „Why God Must Exist”, Science and Christian Belief 1999, vol. 11, no. 1, s. 5-13.

${ }^{19}$ Por. David Bartholomew, God, Chance, and Purpose: Can God Have It Both Ways?, Cambridge University Press, Cambridge 2008.
} 
metafizyczne lub teologiczne. Losowość to pojęcie naukowe, którego nie da się zbadać w pełni na gruncie nauki.

Jeżeli przyjmiemy interpretację instrumentalistyczną, w której twierdzenia ontologiczne nie występują, to nie można mówić o niezgodności pomiędzy tezą o losowości a twierdzeniami tradycyjnej teologii chrześcijańskiej. Jednak przyjęcie interpretacji realistycznej budzi już kontrowersje. W pozostałych częściach artykułu będę argumentował na rzecz zgodności interpretacji realistycznej z klasycznymi chrześcijańskimi poglądami na naturę Boga.

\section{Argumenty za istnieniem losowości ontologicznej}

Gdybyśmy nawet byli w stanie sformułować mocny argument na rzecz spójności między realistyczną interpretacją losowości a ujęciem przymiotów Boga, nie miałby on większego znaczenia, gdyby nie został połączony z wiarygodnym argumentem za istnieniem losowości ontologicznej.

$\mathrm{Z}$ jednej strony teista może argumentować za tym, że losowość i atrybuty Boga się nie wykluczają, wskazując na nieskończoność Boga. Algorytmy mają z konieczności charakter skończony, ludzka wiedza jest ograniczona. W związku z tym nieprzewidywalność i stworzenie wzorców, których nie da się wykryć metodami finitystycznymi, to elementy zgodne z Bożą nieskończonością. Z drugiej strony inny teista może twierdzić, że świat fizyczny ma skończony charakter, i sceptycznie odnosić się do tezy, że dowolny proces fizyczny potrafi wygenerować skutki, którym brak rozpoznawalnego wzorca, mimo że taki proces został stworzony przez Boga. W tej części zaprezentowane zostaną trzy argumenty oparte na obserwacjach świata przyrody, uwiarygodniające tezę o istnieniu losowości ontologicznej.

1. W najnowszych badaniach nad „kwantowymi rzutami monetą" wykorzystano nieokreśloność kwantową do generowania ciągów bitów, które sprawiają silne wrażenie losowych. ${ }^{20}$ ATI wykazała, że istnieją losowe

\footnotetext{
${ }^{20}$ Por. np. „Random Numbers Certified by Bell's Theorem”, Nature 2010, vol. 464, s. 10211024. Por. też Cristian S. Calude, Michael J. Dinneen, Monica Dumitrescu, and Karl Svozil, „Experimental Evidence of Quantum Randomness Incomputability", Physical Review A 2010, vol. 82, s. 022102-1-022102-8, http://tph.tuwien.ac.at/ svozil/pub1/2010-qrat-j.pdf (31.03.2015).
} 
liczby, ale może to oznaczać, że jedynie zaspokoiliśmy abstrakcyjną matematyczną ciekawość. W przypadku kwantowych rzutów monetą potwierdza się wiarygodność tezy, że takie liczby pod istotnymi względami odpowiadają bytom w świecie fizycznym. Za sprawą długoletniego utrzymywania się interpretacji kopenhaskiej oraz dzięki tym badaniom nad kwantowymi rzutami monetą nieokreśloność kwantowa dostarcza mocny argument na rzecz losowości ontologicznej. Nie dowodzi jej istnienia, ale przesuwa ciężar dowodu na tych, którzy temu zaprzeczają.

Niektórzy fizycy argumentowali na podstawie nieokreśloności kwantowej, że nieokreśloność w świecie przyrody dalece wykracza poza poziom kwantowy. W świetle tego argumentu nieokreśloność kwantowa wprowadza nieokreślone stany początkowe do układów chaotycznych i nieokreśloność ta ulega następnie wielokrotnemu wzmocnieniu. Argument ten ma jednak poważną słabość: równania różniczkowe opisujące zachowania chaotyczne (na przykład globalną pogodę) są przybliżeniami stanów makroświata. Mogą więc nie mieć zastosowania na poziomie kwantowym. ${ }^{21}$ Oczywiście kumulatywny efekt wzajemnego oddziaływania olbrzymiej liczby małych cząstek może być wystarczająco duży, by wywierać wpływ na makroukłady. Jednak argument ten ma mniejszą siłę niż życzyliby sobie ci, którzy go wysuwają.

2. Punktem wyjścia innego argumentu za powszechnym występowaniem losowości są procesy Poissona. Pokazują one, że koincydencja wielu niezależnych zdarzeń, które z osobna mogą być deterministyczne, może generować łączny skutek, który jest zgodny z założeniem losowości. Co więcej, świat przyrody jest nadzwyczaj złożony — liczbę cząstek elementarnych szacuje się na $10^{89}$, a niemal każda cząstka nieustannie oddziałuje $\mathrm{z}$ innymi. Także równania różniczkowe wykorzystywane do modelowania wielu układów naturalnych wskazują na ogromną wrażliwość takich układów na warunki początkowe. ${ }^{22}$ Jeśli połączymy te

\footnotetext{
${ }^{21}$ Por. John Polkinghorne, Nauka i Opatrzność. Interakcja Boga ze światem, przeł. Marek Chojnacki, Wiara i Nauka, Wydawnictwo WAM, Kraków 2008, s. 11.

${ }^{22}$ Kilka świetnych artykułów na temat tego zjawiska znajduje się w: Russell, MurPHy, and
} 
czynniki - niezależność, złożoność i chaos - to łatwo zauważyć, że świat wygląda na losowy w dużej skali.

Determinista może argumentować, że świat wydaje się losowy z perspektywy skończonych istot ludzkich, ale nie musi tak być dla nieskończonego, wszechwiedzącego Boga. Twierdzenie to nie wydaje się jednak zgodne z tezą o Boskiej wszechwiedzy, chociaż łatwo da się je pogodzić z tezą o Jego wszechmocy. Rozważmy następujący eksperyment myślowy: inżynier projektuje układ, który utrzymywałby piłkę w miejscu. Może on umieścić ją na szczycie góry i - dysponując dostatecznymi zasobami oraz zachowując czujność — tam ją utrzymywać. Może też umieścić ją w dolinie. W pierwszym przypadku można nazwać go wszechmocnym, ale nie wszechwiedzącym. Zarządzanie naszym światem w sposób deterministyczny, zważywszy na jego nieliniowy charakter, złożoność i wrażliwość na warunki początkowe, przypominałoby umieszczenie piłki na szczycie wzgórza. Zarządzanie nim na zasadzie nieokreśloności przypominałoby natomiast umieszczenie piłki $\mathrm{w}$ dolinie. Innymi słowy, wszechwiedzący inżynier wiedziałby, że układ deterministyczny, który cechuje się tak dużą chwiejnością, nie jest optymalnym projektem.

Argument ten jest zastosowaniem wnioskowania do najlepszego wyjaśnienia i opiera się na analogii między myślami Boga a myślami inżyniera. Ponieważ istnienia losowości ontologicznej nie da się rozstrzygnąc naukowo, takie argumenty pozostają jedyną naszą opcją. Niemniej argument ten nie dotyczy kwestii pojawienia się losowości w świecie fizycznym. To zagadka, której najprawdopodobniej nie będziemy w stanie zgłębić. Ta zagadkowość nie powinna nas jednak dziwić. Jeśli Bóg jest nieskończony, to należy się spodziewać, że natura i działania Boga częściowo pozostaną tajemnicą dla istot skończonych.

3. Podstawą trzeciego argumentu jest wolna wola. Jeśli czyjaś decyzja jest funkcją wielu danych wejściowych, takich jak czynniki genetyczne

Peacocke (eds.), Chaos and Complexity.... Crutchfield i inni, w artykule zatytułowanym po prostu „Chaos” (s. 35-48), piszą o różnych układach naturalnych tego typu, takich jak atmosfera, cieknące krany, wiry opisywane przez mechanikę płynów oraz serce. 
i środowiskowe, to czy ta funkcja ma charakter deterministyczny? Istnieją dwa zasadnicze punkty widzenia. Na kompatybilizm składają się twierdzenia, że jest ona deterministyczna i że takie stanowisko można pogodzić z intuicją, iż mamy wolną wolę. Natomiast inkompatybilizm głosi, że ludzkie decyzje nie mają natury deterministycznej. Argument z wolnej woli na rzecz istnienia losowości zakłada słuszność inkompatybilizmu.

Jeśli inkompatybilistycznie rozumiana wolna wola istnieje, to istnieje również losowość ontologiczna, ale relacja odwrotna nie musi zachodzić. Rozważmy przykład rzutów monetą. Inżynier przypuszczalnie mógłby zaprojektować „predyktor rzutów monetą”, czyli maszynę wykrywającą wyjściową pozycję monety, początkowe prędkości lotu do góry i obrotów oraz pozycję, w jakiej moneta wyląduje, i w ten sposób przewidującą końcowy wynik. Tak więc wynik rozpoczętego już rzutu monetą jest deterministyczny. Jeżeli jednak osoba, która rzuca monetą, ma inkompatybilistyczną wolną wolę, to dokładny moment i sposób podrzucenia są nieprzewidywalne $\mathrm{w}$ zasadzie $\mathrm{i}$ wręcz nie znajdują się pod pełną kontrolą tej osoby. Czyli zanim moneta zostanie podrzucona, wynik rzutu jest ontologicznie nieokreślony. Ponieważ inkompatybilistyczna wolna wola z konieczności pociąga za sobą losowość ontologiczną, więc zaprzeczenie losowości ontologicznej implikuje kompatybilizm.

Niektórzy naukowcy argumentowali, że kopenhaska interpretacja nieokreśloności kwantowej, o ile jest słuszna, umożliwia wyjaśnienie inkompatybilistycznej wolnej woli. Opowiadają się oni za wiarygodnością relacji odwrotnej - że losowość ontologiczna może thumaczyć wolną wolę. Niemniej trudno zrozumieć, jak taki argument miałby przebiegać. Na przykład punktem wyjściowym jednej z odmian tego argumentu jest nieokreśloność kwantowa cząstek elementarnych w mózgu danej osoby. Aby jednak wyjaśnić wolną wolę, argument ten musi „połączyć kropki” między nieokreślonością a konkretnymi wolnymi wyborami. Nie bardzo wiadomo, czy da się to zrobić. ${ }^{23}$

\footnotetext{
${ }^{23}$ Por. Harald Atmanspacher, „Quantum Approaches to Consciousness”, w: Stanford Encyc-
} 
Zauważmy, że jeśli inkompatybilistyczna wolna wola istnieje, to gry losowe mogą przejawiać losowość ontologiczną, ponieważ znajdują się pod kontrolą podmiotu działającego w sposób nieokreślony. Co więcej, taka sama sytuacja zachodziłaby w przypadku liczb pseudolosowych i próbkowania losowego - nieokreślony ontologicznie wybór może uruchomić generator losowych liczb.

Argumenty odwołujące się do procesów fizycznych prowadzą do mocniejszego twierdzenia o losowości niż argument $\mathrm{z}$ wolnej woli. Te pierwsze umieszczają losowość w strukturze świata fizycznego, zapewniając jej ramę czasową liczącą miliardy lat oraz niezależność od aktywności człowieka.

Teza, że świat fizyczny jest w znacznym stopniu nieokreślony, może wydawać się niewiarygodna ze względu na jego uporządkowanie i przewidywalność. Ponadto, wielu ludziom wydaje się ona niespójna z ujęciem natury Boga. Problem ten rozważymy w Częściach 5-10.

\section{Natura Boga}

Rozstrzygnięcie, czy natura Boga nie wyklucza losowości, wymaga zrozumienia tej pierwszej. Teologowie systematyczni szeroko pisali na ten temat. Niektórzy wskazywali, że skończone istoty ludzkie nie są zdolne pojąć transcendentnego, nieskończonego Boga. W tradycyjnej myśli chrześcijańskiej panuje konsensus, że możemy formułować trafne, choć z konieczności niekompletne, twierdzenia o naturze Boga, ponieważ Bóg objawił się w Piśmie Świętym.

W ramach ujęcia prototypowego wymienia się i omawia listę Bożych przymiotów. Na przykład Thomas Oden przedstawia zbiory Bożych atrybutów zorganizowane wokół czterech tematów:

- Istota Boga (główne i istotne przymioty Boga: wystarczalność, istnienie niepochodne, jedność, nieskończoność, niezmierzoność, wieczność, życie)

lopedia of Philosophy, ed. Edward N. Zalta, Summer 2011, http://plato.stanford.edu/archives/sum 2011/entries/qt-consciousness/ (01.04.2015). 
- Majestat Boży (relacyjne atrybuty Boga: wszechobecny, wszechwiedzący, wszechmocny)

- Osoba Boska (wolny, kongruentny, interaktywny Duch)

- Dobroć Boża (święty, stały, współczujący) ${ }^{24}$

„Kongruentny” znaczy, że Bóg działa w sposób spójny ze swoją istotą i charakterem — „nie może wyrzec się samego siebie”. „Relacyjny” odnosi się do związku Boga z całością stworzenia.

Herman Bavinck omawia atrybuty Boga, posługując się imionami Bożymi objawionymi w Piśmie Świętym. ${ }^{25}$ Jego lista jest podobna do listy Odena. Szczegółowo przedstawia on również historię myśli chrześcijańskiej na temat tych atrybutów. Wielu innych teologów, zwłaszcza Tomasz z Akwinu w Sumie teologicznej i Jan Kalwin w Ustanowieniu religii chrześcijańskiej, w systematyczny sposób opisywało Boże przymioty. Przedstawione przez Odena cztery zbiory atrybutów stanowią reprezentatywne ich podsumowanie.

Atrybuty istotne nie mają żadnego związku z losowością, ponieważ dotyczą tego, kim jest Bóg w odłączeniu od stworzenia. ${ }^{26}$ Również atrybuty osoby Boskiej i dobroci Bożej nie mają nic wspólnego ze związkiem Boga z procesami fizycznymi. Tak więc, uwzględniając listę Odena, wszystkie potencjalne problemy z uzgodnieniem losowości i natury Boga wiążą się z przymiotami relacyjnymi - wszechmocą, wszechwiedzą i wszechobecnością.

${ }^{24}$ Por. Thomas C. Oden, Classic Christianity: A Systematic Theology, HarperOne, New York 1992, s. 35 i n.

${ }^{25}$ Por. Herman BAvinck, Reformed Dogmatics, Volume 2: God and Creation, Baker Academic, Grand Rapids, Michigan 2004.

${ }^{26}$ Część teologów mówi o atrybutach Bożych „wyprzedzających” stworzenie. Jednak czas zwykle również postrzegany jest jako część stworzonego porządku. Zatem zwrot „wyprzedzający stworzenie", jeśli ma wskazywać na następstwo czasowe, nie ma sensu. Niemniej autorzy ci używają tego zwrotu nie w znaczeniu temporalnym, lecz w sensie stworzenia zależnego od Boga przy braku relacji odwrotnej. Wolę uniknąć nieporozumień i dlatego posługuję się zwrotem „w odłączeniu od”, odnosząc się do atrybutów, które byłyby przypisane Bogu, nawet gdyby stworzenie nie istniało. 


\section{Wszechmoc}

Oden proponuje zwięzłą definicję wszechmocy: Boża „doskonała zdolność do robienia wszystkiego, co spójne jest z Jego charakterem”. Bavinck opisuje wszechmoc na różne sposoby. Najjaśniejsze opisy są następujące:

- „Ma absolutną władzę nad wszystkim i nic nie może mu się oprzeć”.

- „Nic nie jest dla Boga zbyt trudne: dla Niego wszystko jest możliwe”.

- „Robi, co tylko zechce, i nikomu nie musi się thumaczyć”.

- „Wreszcie, ta moc Boża jest także źródłem każdej władzy i autorytetu, zdolności i siły w stworzeniach". ${ }^{27}$

Omawiając nominalizm, Bavinck wyjaśnia też, czego wszechmoc nie oznacza.

[...] nominaliści definiowali wszechmoc Bożą nie tylko jako zdolność Boga do robienia wszystkiego, co zechce, ale także jako Jego zdolność do chcenia wszystkiego. Rozróżniając między Bożą mocą , ,absolutną” a mocą , uporządkowaną”, sądzili, że w zgodzie z tą pierwszą Bóg może również grzeszyć, błądzić, cierpieć, umrzeć, przemienić się w kamień lub zwierzę, zmienić chleb w ciało Chrystusa, robić wzajemnie sprzeczne rzeczy, unieważnić przeszłość, z prawdy uczynić fałsz, z fałszu prawdę i tak dalej. Zatem w perspektywie swej mocy absolutnej Bóg jest czystą arbitralnością, absolutną możnością pozbawioną treści, która jest niczym, ale może stać się wszystkim. ${ }^{28}$

Niemniej Bavinck ogranicza wszechmoc Boga jedynie w zakresie robienia rzeczy wzajemnie sprzecznych i niespójnych z Jego naturą. Dodaje: „To, co możliwe, dalece przekracza to, co rzeczywiste”. Innymi słowy, odrzuca on stanowisko Abelarda, zgodnie z którym Bóg nie może robić niczego ponad to, co robi. Bavinck wskazuje też, że:

Kalwin nie przeczył, że Bóg może robić więcej niż rzeczywiście zrobił, a tylko sprzeciwiał się koncepcji „mocy absolutnej”, która nie jest ograniczona przez Jego naturę i dlatego może robić wzajemnie sprzeczne rzeczy. To rozróżnienie, pojmowane w zgo-

\footnotetext{
${ }^{27}$ Bavinck, God and Creation..., s. 246.

${ }^{28}$ B AVINCK, God and Creation..., s. 247.
} 
dzie z myślą Augustyna i Tomasza, było powszechnie akceptowane przez teologów reformowanych i w takim rozumieniu było dla nich warte akceptacji. ${ }^{29}$

Bavinck wskazuje pewien potencjalny problem z uzgodnieniem losowości i natury Boga: chociaż losowość nie jest niespójna z charakterem Boga, to zdaje się obejmować procesy wymykające się Boskiej kontroli. Bez wzorca lub przewidywalności trudno mówić o kontroli. Losowość wydaje się więc niezgodna z Bożą wszechmocą. Zagadnienie to będzie analizowane w Części 7.

\section{Wszechwiedza}

Oden definiuje Boską wszechwiedzę jako „kompletną wiedzę Boga o świecie i czasie”. ${ }^{30}$ Jednym z biblijnych źródeł jest Hbr 4:13: „Nie ma stworzenia, które by dla Niego było niewidzialne; przeciwnie, wszystko odkryte jest i odsłonięte przed oczami Tego, któremu musimy zdać rachunek" (BT). Oden pisze, że:

Bożą wiedzę uznaje się za (a) wiecznie aktualną, a nie tylko potencjalną; (b) wiecznie doskonałą w odróżnieniu od wiedzy, która ma swój początek, wzrasta, maleje lub dobiega końca; (c) kompletną, nie zaś tylko częściową; (d) bezpośrednią i natychmiastową w odróżnieniu od uzyskiwanej pośrednio czy za czyjąś pomocą. ${ }^{31}$

Dla Odena wszechwiedza to mądrość, a także wiedza faktualna:

Mądrość Boża to niezrównana zdolność Boga do porządkowania wszystkiego podług dobroci, dostosowywania przyczyn do skutków, środków do celów. Zamysły Boga są więc niewzruszone i nigdy nie zostają udaremnione. ${ }^{32}$

Kwestia wszechwiedzy stwarza dwa problemy. Pierwszy polega na tym, że w potocznym rozumieniu przypadek nie jest wynikiem projektu, nie można ująć go metodycznie, nie ma celu. Istnienie przypadku przeczyłoby więc poglądowi,

\footnotetext{
${ }^{29}$ Bavinck, God and Creation..., s. 249.

${ }^{30}$ Oden, Classic Christianity..., s. 46.

${ }^{31}$ Oden, Classic Christianity..., s. 49.

${ }^{32}$ Oden, Classic Christianity..., s. 49.
} 
że Bóg nadał cel całemu stworzeniu i porządkuje wszystko zgodnie z nim. Na przykład w Księdze Izajasza Bóg mówi: ,uczynię wszystko, co zechcę” (Iz $46: 10 b[B T])$.

Część 6 poświęcona jest naszemu drugiemu problemowi — pogodzeniu losowości z Bożą celowością. Można argumentować, że nawet jeśli jakiś proces wydaje się losowy, Bóg wie, co się wydarzy, a tym samym każdy rezultat jest dla Boga przewidywalny. Jeżeli zaś jest przewidywalny dla Boga, to może i dla człowieka. Przeczy to nieprzewidywalności, którą łączy się z losowością. Bavinck wspiera to stanowisko, powołując się na Cycerona: ,„...] jeśli on [Bóg] to wie, to na pewno będzie miało to miejsce, ale jeżeli musi mieć to miejsce, to nie istnieje nic takiego, jak przypadek". ${ }^{33}$ Problemem tym zajmę się w Części 8.

\section{Wszechobecność}

Oden definiuje wszechobecność jako „Boski sposób bycia obecnym we wszystkich aspektach czasu i przestrzeni. Mimo że Bóg jest obecny w każdym miejscu i czasie, to nie jest lokalnie ograniczony do jakiegoś konkretnego miejsca lub czasu". ${ }^{34}$

Tomasz z Akwinu pisze:

Bóg jest we wszystkim swoją potęgą, gdyż wszystko podlega Jego władzy; jest we wszystkim swoją obecnością, gdyż wszystko gołe i otwarte jest dla Jego wzroku; jest wreszcie we wszystkim swoim jestestwem, istotą, gdyż o czym wyżej była mowa, jako przyczyna istnienia, musi być przy każdym swoim dziele [...]. ${ }^{35}$

W Stanford Encyclopedia of Philosophy podniesiono filozoficzne pytanie o wszechobecność: „Jak niematerialny byt może być obecny lub umieszczony w przestrzeni?" Objaśniona jest tam odpowiedź Akwinaty:

\footnotetext{
${ }^{33}$ BAvinck, God and Creation..., s. 202.

${ }^{34}$ Oden, Classic Christianity..., s. 43.

${ }^{35}$ Tomasz z Akwinu, Suma teologiczna, przeł. Pius Bełch, t. 1, Veritas, London 1975, cz. I, zag. 8 , art. 3 .
} 
W tym rozumieniu obecności Boga, poprzez odwołanie się do Jego potęgi i wiedzy, predykat , jest obecny” traktuje się w taki sposób, że odnosi się do Boga analogicznie jak do zwykłych zjawisk fizycznych. Nie jest on ani jednoznaczny (używany w tym samym znaczeniu, jak w zwykłych kontekstach), ani niejednoznaczny (używany w różnych znaczeniach). Jego znaczenie można wyjaśnić raczej przez odniesienie do jego zwykłego sensu: Bóg jest obecny w danym miejscu tylko wówczas, gdy znajduje się tam jakiś obiekt fizyczny, i Bóg ma nad nim władzę, wie, co się w nim dzieje, a także jest przyczyną jego istnienia. ${ }^{36}$

Wszechobecność w sensie bycia obecnym w każdym miejscu i czasie nie jest niespójna z losowością. Jednakże obecność Boga w każdym akcie przyczynowym stwarza czwarty problem: w przypadku przyczynowości deterministycznej, jeśli następuje A, z konieczności zachodzi po nim $\mathrm{B}$ i albo A jest mechanizmem wytwarzającym $\mathrm{B}$, albo A uruchamia taki mechanizm. ${ }^{37} \mathrm{~W}$ przypadku przyczynowości probabilistycznej, jeśli zachodzi A, to wzrasta prawdopodobieństwo B. Na przykład palenie powoduje raka płuc, ale nie wszyscy palacze chorują na raka płuc, a także nie każdy chory na raka płuc jest palaczem. Palenie zwiększa jednak prawdopodobieństwo zachorowania na raka płuc. Procesy mające przyczyny deterministyczne (takie jak te dyskutowane w części poświęconej Wzorcowi 9) mogą cechować się losowością epistemiczną, ale procesy mające przyczyny probabilistyczne (o ile są czymś więcej niż jedynie wyrazem ludzkich ograniczeń) mogą odzwierciedlać losowość ontologiczną. Niemniej ze względu na to, że Bóg jest wszechwiedzący, w pełni rozumie mechanizmy działania wszystkich procesów fizycznych. Przez to istnienie przyczynowości probabilistycznej, a tym samym losowości, staje pod znakiem zapytania. Temu problemowi poświęcona będzie Część 9.

\section{Cel}

Ludzie celowo posługują się losowością na wiele sposobów — przykłady to gry losowe, liczby pseudolosowe, losowe próbkowanie. W tej części argumentu-

\footnotetext{
${ }^{36}$ Edward Wierenga, „Omnipresence”, w: Stanford Encyclopedia of Philosophy, ed. Edward N. Zalta, 2009, http://plato.stanford.edu/entries/omnipresence/ (01.04.2015).

${ }^{37}$ Wzmianka o mechanizmie jest istotna. Jeśli na przykład A to fakt, że ciśnienie powietrza w pewnej lokalizacji spada, a B to fakt, że następuje burza, to B z konieczności zachodzi po A, lecz A nie jest przyczyną B.
} 
ję, że Bóg korzysta z losowości, aby osiągnąć swoje cele, a tym samym zarzuty wobec koncepcji losowości, których podstawą jest celowe działanie Boga, są bezzasadne. Zakładam, że przykłady omawiane w tej części wskazują na losowość ontologiczną, i przekonuję o spójności tego założenia z ujęciem natury Boga.

Robert Bishop wymienia kilka celów, jakie Bóg nadał stworzeniu: (1) ukazywać Jego chwałę; (2) służyć jako Jego świątynia; (3) „stanie się wyłącznie tym, co nazywane jest byciem w Chrystusie"; (4) zapełnienie stworzenia życiem; oraz (5) „bycie areną ogólnego odkupienia”. ${ }^{38}$ Losowość przyczynia się do osiągnięcia (przynajmniej) pierwszego i czwartego celu dzięki utrzymywaniu równowagi dynamicznej w układach złożonych. Rozważmy następujące przykłady:

- Każda komórka organizmów żywych musi transportować składniki odżywcze do swego wnętrza i pozbywać się odpadów. Za czynności te odpowiada osmoza, która - o czym była mowa w Części 2 - polega na losowym ruchu cząsteczek.

- Mówiąc ogólniej, dyfuzja to wszechobecne zjawisko, którego funkcją jest wyrównywanie rozkładów temperatury i ciśnienia powietrza. Dyfuzja umożliwia na przykład przybranie jednolitego kształtu przez balon, mimo że w jego wnętrzu zachodzi losowy ruch cząsteczek powietrza.

- Różnorodność genetyczna umożliwia populacjom adaptację do zmiennych warunków środowiskowych. ${ }^{39} \mathrm{Na}$ przykład ornitolodzy, na podstawie szczątków szkieletów, oszacowali, że zanim Polinezyjczycy odbyli migrację na Hawaje w pierwszym tysiącleciu n.e., Wyspy Hawajskie zamieszkiwało ponad sto gatunków błękitniczków. Ornitolodzy uważają je za podrodzinę Drepanidinae rodziny Fringillidae, czyli rodziny zięb. Zięby żywią się nasionami. Do hawajskich błękitniczków zaliczają się nie tylko ptaki żywiące się ziarnem, ale także owadami,

\footnotetext{
${ }^{38}$ Robert C. Bishop, „Recovering the Doctrine of Creation: A Theological View of Science”, http://biologos.org/uploads/static-content/bishop_white_paper.pdf(02.04.2015).

${ }^{39}$ Ten wypunktowany fragment pojawia się również w: James BradLEy and Russell Howell, Mathematics through the Eyes of Faith, HarperOne, New York 2011, s. 108. Copyright 2011 by the Council for Christian Colleges and Universities. Przedruk za zgodą HarperOne.
} 
nektarem, owocami, a nawet ślimakami czy też takie, które przeszukują gnijące drewno w poszukiwaniu owadów. Wyjaśniając unikalność i różnorodność hawajskich błękitniczków, ornitolodzy przyjmują, że w przeszłości jedna para (lub więcej) zięb dostała się na wyspy za sprawą silnych wiatrów. Nie mając konkurentów, hawajskie błękitniczki ewoluowały tak, by móc wykorzystać bogate zasoby dostępne w niszach ekologicznych, które normalnie nie są zajmowane przez zięby. Powstanie tej różnorodności umożliwiły losowe procesy genetyczne. Pozwoliły one na dobre wykorzystanie zasobów, a przy okazji wytworzyły niezwykłe bogactwo pięknych ptaków. ${ }^{40}$

Można podać jeszcze wiele przykładów celowej roli losowości z dziedzin sztucznej inteligencji, teorii hierarchii, teorii gier i mechaniki kwantowej, ale te powyższe wystarczą. Wygląda więc na to, że losowość, często uznawana za synonim bezładu i niestabilności, jest mechanizmem, który tworzy porządek, stabilność i różnorodność w sytuacjach fizycznych, od których zależy życie. Możemy zatem rozumować w sposób następujący: Bóg jest Stwórcą wszystkich rzeczy i wymieniliśmy niektóre cele, jakie nadał on stworzeniu. Wiemy, jak losowość pomaga w osiągnięciu tych celów. Dlatego możemy wnioskować przez analogię od tego, jak my realizujemy cele, do tego, jak może realizować je Bóg, i wysnuć wniosek, że Bóg stworzył losowość, aby osiągnąć swoje cele.

Chociaż powyższe przykłady są dobrze zrozumiałe, niektórzy autorzy sformułowali dodatkowe idee spekulatywne odnośnie do tego, jak Bóg może posługiwać się losowością.

- W rozdziale zatytułowanym „Porządek z chaosu” David Bartholomew przytacza przykłady tego, jak uporządkowane struktury powstają nieoczekiwanie z chaotycznych układów takich obiektów jak żarówki i przełączniki. Jak pisze: „Losowość łatwo prowadzi do tego, co mogłoby być bardzo trudne do uzyskania na zasadzie projektu". ${ }^{41}$ Dla Bartho-

\footnotetext{
${ }^{40}$ Inny dobitny przykład tego zjawiska opisany jest w: Jonathan Weiner, Dziób zięby, czyli jak dziś przebiega ewolucja, przeł. Monika Betley, Książka i Wiedza, Warszawa 1997.

${ }^{41}$ Bartholomew, God, Chance, and Purpose..., s. 49.
} 
lomew ustalenie to służy jako analogia tłumacząca, jak Bóg może mieć jednocześnie losowość i porządek.

- Mówiąc o prawie naukowym, John Polkinghorne pisze: „Przypadek natomiast jest $\mathrm{w}$ tym kontekście narzędziem, dzięki któremu — wskutek ciągłej zmienności (a zatem i przygodności) pojawiających się wciąż nowych jednostkowych stanów - ujawniają się i realizują ukryte możliwości koniecznych praw". ${ }^{42}$ Innymi słowy, według Polkinghorne’a Bóg obdarza stworzenie możliwościami. Losowość zapewnia środki do ich eksploracji, pozwalając tym samym na kreatywność w świecie fizycznym.

- William Pollard, znany fizyk i ksiądz Kościoła Episkopalnego, opowiadał się za nieokreślonością kwantową. Mówił też jednak, że losowość na poziomie makroskopowym stwarza miejsce dla działania opatrznościowego, które niełatwo rozpoznać jako niezwykłe. ${ }^{43}$ Pollard sugeruje w ten sposób, że świat nie jest deterministyczny, a nieustanne działanie Boskie przejawia się w formie Boskiej troski opatrznościowej. Tyle że losowość umożliwia Bogu ukrycie tych działań. Tym samym Bóg gwarantuje, że interpretowanie wydarzeń jako aktów opatrznościowych będzie zależało od wiary. Takie interpretacje nie są wymuszane na każdym człowieku.

Losowość nie wyklucza zatem celowej aktywności Boga.

\section{Wladza}

Naszym drugim potencjalnym problemem jest to, że losowość zdaje się obejmować procesy, które znajdują się poza kontrolą Boga, a więc że losowość wyklucza Bożą wszechmoc. Oden pisze:

\footnotetext{
${ }^{42}$ Polkinghorne, Nauka i Opatrzność..., s. 79.

${ }^{43}$ Por. William Pollard, Chance and Providence: God's Action in a World Governed by Scientific Law, Scribner, New York 1958.
} 
Władza Boga nie jest zawsze związana z realizacją każdej formy władzy w każdej sytuacji. [...] Bóg pozwala nawet na akty woli, które przeczą Boskiej woli działania i wywierania wpływu w ulotnych, temporalnych granicach świata. ${ }^{44}$

Tomasz z Akwinu postrzegał Boga jako nadającego możność przyrodzie i podtrzymującego, a nie kontrolującego, ją. Stworzenia mogą odgrywać rolę czynników przyczynowych same w sobie i względem siebie. ${ }^{45}$ Dla Akwinaty Bóg nie jest tylko kolejną przyczyną czy bytem we Wszechświecie, lecz nadaje wszystkim innym rzeczom byt, uporządkowanie i zdolność do działania jako przyczyna wtórna. W tej części bardziej szczegółowo przeanalizuję pogląd Tomasza i Odena.

Po pierwsze, losowości może towarzyszyć uporządkowanie. Jeśli rzucimy uczciwą kostką i nie wydarzy się nic bardzo niezwykłego, jak połknięcie kostki przez rodzinnego psa, to istnieje tylko sześć możliwych wyników, a każdy ma prawdopodobieństwo 1/6. Sytuacja ta bliższa jest deterministycznemu uporządkowaniu niż zupełnemu chaosowi. Wszelki porządek bierze się zaś od Boga $\mathrm{i}$ jest to prawda również $\mathrm{w}$ odniesieniu do uporządkowania widocznego $\mathrm{w}$ procesach losowych. Jak wskazuje Michał Heller, prawa prawdopodobieństwa to przecież ciągle prawa. ${ }^{46}$

David Bartholomew argumentuje, że Bóg „może mieć jedno i drugie” — losowość i porządek - jeśli wprowadzimy koncepcję poziomu. Na poziomie indywidualnych bytów dana sytuacja może mieć charakter losowy, ale na poziomie ogólnym może charakteryzować się uporządkowaniem. ${ }^{47}$ Na przykład:

- W skali globu rodzi się około 106 dzieci płci męskiej na 100 dzieci płci żeńskiej. Jednak dzieci płci męskiej wykazują wyższy stopień śmiertelności w wieku dziecięcym, a więc gdy przedstawiciele obu płci osiągają

\footnotetext{
${ }^{44}$ Oden, Classic Christianity..., s. 53.

${ }^{45}$ Jestem wdzięczny Williamowi Stoegerowi SJ, który wyjaśnił mi, jakie jest spojrzenie Tomasza na tę kwestię.

${ }^{46}$ Por. Michael Heller, Creative Tension: Essays on Science and Religion, John Templeton Foundation Press, West Conshohocken, Pennsylvania 2003, rozdz. 11.

${ }^{47}$ Większość materiału w tej części artykułu znajduje się też w: BradLEy and Howell, Mathematics through the Eyes of Faith..., s. 105-106.
} 
wiek dojrzały, liczba mężczyzn i kobiet jest niemal równa. Zatem płeć indywidualnego noworodka może być nieokreślona, ale po zsumowaniu otrzymujemy proste uporządkowanie.

- Prawo gazu doskonałego po raz pierwszy sformułowane zostało przez Émile'a Clapeyrona w 1834 roku. Dla gazu zamkniętego w pojemniku $\mathrm{PV}=\mathrm{NRT}$, gdzie $\mathrm{P}$ oznacza ciśnienie, $\mathrm{V}$ - objętość, $\mathrm{N}$ - ilość gazu, $\mathrm{R}$ - stałą gazową, a T - temperaturę. Gaz składa się z olbrzymiej liczby cząsteczek poruszających się losowo w pojemniku. Prawo gazu opisuje ich zsumowane zachowanie w prosty, uporządkowany sposób.

Rysunek 1 przedstawia rozkład prawdopodobieństwa. Zwróćmy uwagę na zmienny, nierówny charakter tego rozkładu. Za pomocą komputera z tak rozłożonej populacji dobrałem 10000 losowych prób o wielkości 30. Rysunek 2 pokazuje rozkład średnich wartości tych prób. Jest on podobny do znanej krzywej dzwonowej. Centralne twierdzenie graniczne mówi, że dla każdego rozkładu prawdopodobieństwa zachodzi zależność, taka że jeżeli weźmiemy niezależne losowe próby o wielkości $\mathrm{n}$ z tej populacji, to rozkład średniej wartości tych prób zbliża się do rozkładu normalnego wraz ze zwiększaniem n. Procesy uśredniające duże liczby podobnych elementów występują powszechnie. Na przykład temperatura to uśredniony ruch cząsteczek. Tak więc centralne twierdzenie graniczne dostarcza potężne wyjaśnienie, dlaczego rozkłady normalne są tak częste w przyrodzie. Pokazuje ono, jak sumowanie przekształca nieład na jednym poziomie w porządek na poziomie wyższym.

Bartholomew przekonuje, że władza Boga funkcjonuje odmiennie na różnych poziomach. Osoba wierząca bez problemu może twierdzić, że porządek i struktura na poziomach ogólnych wyrażają Boży ład i Bożą dobroć. Bartholomew twierdzi jednak, że losowość na niższych poziomach także wyraża Bożą władzę. Niemniej, mimo że rozważania Bartholomew o poziomach pomagają zrozumieć, dlaczego „Bóg może mieć jedno i drugie”, to jeśli będziemy rozpatrywać je w izolacji, mogą one upraszczać złożoność rzeczywistości. Stworzenia nie da się gładko podzielić na dwa poziomy — niższy, na którym Bóg działa poprzez losowość, i wyższy, na którym przeważają prawa deterministyczne. 


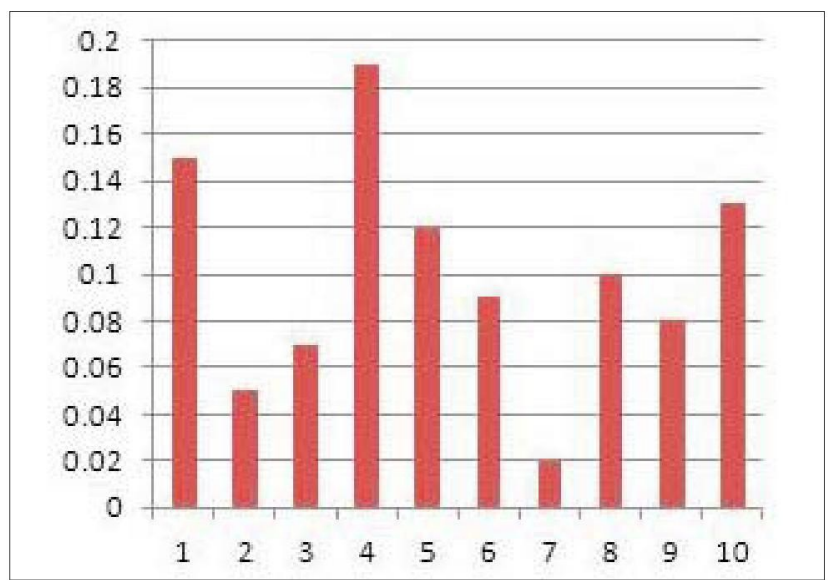

Rysunek 1. Rozkład prawdopodobieństwa.

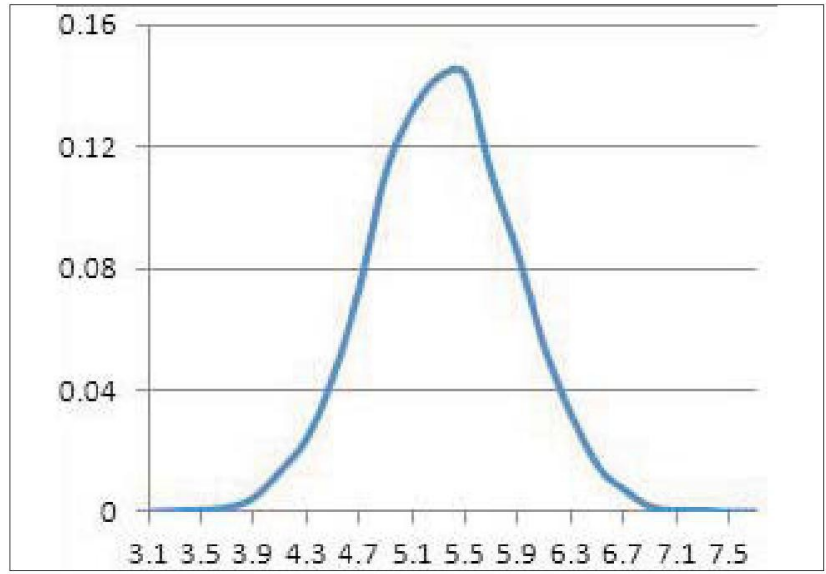

Rysunek 2. Rozkład średnich wartości losowych prób z Rysunku 1.

Pomocne okazuje się tu wprowadzone przez Roberta Bishopa pojęcie przygodnej racjonalności, czyli porządku i struktury, które zostały nadane stworzeniu w wolnym akcie Boga. Bishop pisze, że ,[...] stworzenie ma swoją własną racjonalność, swoje własne szczególne uporządkowanie, strukturę i funkcjonal- 
ność, które przynajmniej częściowo są dla nas pojmowalne”. ${ }^{48}$ Bóg działa poprzez tę racjonalność i dotyczy to również praw prawdopodobieństwa oraz uporządkowanego charakteru procesów losowych. Losowość nie jest równoznaczna $\mathrm{z}$ dowolnością. Jest raczej tak, że zjawiska losowe są w taki sposób urządzone, by działać w granicach określonych przez swoją naturę. Cząsteczki mogą drgać w każdym kierunku trójwymiarowej przestrzeni, ale to wszystko, co są w stanie robić. Gładki groch może w sposób indeterministyczny płodzić potomstwo gładkie lub szorstkie, ale nie może spłodzić goryla. Zwierzchnia kontrola Boga nad losowością wyrażona jest w obu typach praw probabilistycznych — tych, które funkcjonują na poziomie indywidualnych bytów, i tych, które rządzą sumowaniem.

\section{Przedwiedza}

Próba pogodzenia losowości z Boską przedwiedzą to ogólniejsza wersja klasycznego problemu pogodzenia wolnej woli człowieka z Boską przedwiedzą powstają tu takie same pytania. W traktacie $\mathbf{O}$ wolnej woli Augustyn formułuje ten problem słowami swojego interlokutora, Ewodiusza:

Wobec tego jestem poważnie zaniepokojony, jak można pogodzić to, że Bóg zna z góry całą przyszłość i że my, grzesząc, nie ulegamy przeznaczeniu. Przecież każdy, kto powie, że jakieś wydarzenie może mieć przebieg inny, niż Bóg przedtem przewidział, ten jest szaleńcem i bezbożnikiem, który usiłuje obalić przekonanie, że Bóg zna przyszłość. Toteż, jeżeli Bóg przewidział grzech pierwszego człowieka (a to musi przyznać mi każdy, kto razem ze mną uznaje Bożą znajomość przyszłości), to nie twierdzę wprawdzie, że nie powinien był stwarzać go, bo stworzył go dobrym i nie mógł przeszkadzać Bogu grzech istoty, którą Sam stworzył jako dobrą [...]. Toteż powtarzam - nie twierdzę, że nie powinien był stwarzać człowieka, lecz że grzech przewidziany przez Boga musiał nastąpić. Jak więc można mówić o wolnej woli tam, gdzie widzimy tak nieuchronną konieczność? ${ }^{49}$

\footnotetext{
${ }^{48}$ Bishop, „Recovering the Doctrine of Creation...”.

${ }^{49}$ Św. Augustyn, „O wolnej woli”, przeł. Anna Trąbala, w: Św. Augustyn, Dialogi filozoficzne, oprac. Władysław Seńko, Wydawnictwo Znak, Kraków 1999, s. 584 [493-649]. (Ze względu na odmienny styl przyjęty w polskim przekładzie zamieszczono tu nieco dłuższy fragment dzieła Św. Augustyna od zacytowanego przez Autora niniejszego artykułu — przyp. tłum.)
} 
Zastępując grzeszenie zdarzeniami losowymi, a wolną wolę procesami, które wywołały zdarzenia losowe, otrzymujemy problem pogodzenia losowości z Bożą przedwiedzą. Trzy sposoby godzenia Bożej przedwiedzy z wolną wolą człowieka mają także zastosowanie do losowości w świecie przyrody. ${ }^{50}$

1. Zwolennicy teizmu otwartego głoszą, że przyszłość nie istnieje. Przyjmują oni, że Bóg ma wiedzę o wielu przyszłych zdarzeniach — zna swoje plany na przyszłość, ma pełną wiedzę o prawach przyrody, a więc potrafi przewidzieć przyszłą ewolucję wszystkiego, co podlega tym prawom. Zna również zsumowane zachowanie układów indeterministycznych. Nie dysponuje jednak wiedzą osiągalną drogą obserwacji jakiegoś konkretnego przyszłego zdarzenia. Jeśli planuję rzucić monetą za pięć minut, to - zgodnie $\mathrm{z}$ teizmem otwartym - Bóg nie może przewidzieć, czy wypadnie orzeł czy reszka. Zwolennicy tego podejścia argumentują, że ten fakt nie przeczy Bożej wszechwiedzy — Bóg wie wszystko, o czym można mieć wiedzę, ale z tego względu, że nieokreślone przyszłe zdarzenia nie istnieją, nie można mieć o nich wiedzy. Wskazują oni też na różne teksty biblijne mówiące o tym, że Bóg żałuje swoich czynów, zmienia zdanie i tak dalej, i interpretują je jako potwierdzenie, że przyszłość jest otwarta.

2. Inne podejście to koncepcja prostej przedwiedzy, czyli pełnej i niepodważalnej Bożej wiedzy o przyszłości, „,[...] niekomplikowanej przez wyjątki, dodatki, kwalifikacje i tym podobne [...]". ${ }^{51}$ Argumenty na rzecz prostej przedwiedzy wykazują, że przedwiedza nie nakłada ograniczeń na zdarzenia. Rozważmy dowolne zdarzenie, które można uznać za losowe - na przykład dokonanie pomiaru spinu jakiegoś konkretnego elektronu. Wyobraźmy sobie, że Bóg, pomimo swojej wszechwiedzy, decyduje się zignorować to konkretne zdarzenie. (Być może nie jest w stanie tego zrobić, ale przyjmijmy tę hipotezę na potrzeby naszej

\footnotetext{
${ }^{50}$ Wszystkie trzy zostały klarownie przedstawione w: James K. BeILby and Paul R. EdDy (eds.), Divine Foreknowledge: Four Views, InterVarsity Press, Downers Grove, Illinois 2001. Książka ta przedstawia też argumentację na rzecz determinizmu, którą tu pominę, ponieważ moim celem jest jedynie wykazanie, że teza o losowości ontologicznej jest zgodna z tradycyjnymi poglądami na naturę Boga.

${ }^{51}$ David Hunt w: Divine Foreknowledge: Four Views..., s. 67.
} 
argumentacji.) Bóg nie dysponuje przedwiedzą o tym, czy po pomiarze spin tego elektronu będzie skierowany do góry czy w dół, a losowy charakter tego wyniku nie wyklucza Jego przedwiedzy. Zdarzenie jest natomiast dokładnie takie samo bez względu na to, czy Bóg o nim wie. Losowy charakter tego zdarzenia jest więc niezależny od Bożej przedwiedzy.

3. Trzecim podejściem jest molinizm, który swoją nazwę wziął od szesnastowiecznego jezuickiego uczonego Luisa de Moliny. Wyobraźmy sobie Boga kontemplującego wszystkie możliwe światy, jakie byłby w stanie stworzyć. Moliniści wiedzę o tych światach nazywają Boska wiedza naturalna. Teraz wyobraźmy sobie Boga po tym, jak już wybrał jeden świat, w którym żyjemy my (wyrażenie „po tym” użyte jest tu w znaczeniu logicznym, nie zaś temporalnym). Jego wiedza na ten temat nazywana jest wiedza wolna (ponieważ w wolnym akcie wybrał On, który świat stworzyć). Moliniści argumentują, że pośrodku tych dwu rodzajów wiedzy znajduje się jeszcze tak zwana Boska wiedza pośrednia, to jest wiedza o zdarzeniach (które mogą być losowe) w każdym z możliwych światów. Według molinistów Bóg, decydując się na stworzenie tego konkretnego świata, wziął pod uwagę tę pośrednią wiedzę. To dlatego może on stworzyć losowość, mieć przedwiedzę o jej skutkach i zagwarantować, że Jego wola się wypełni - nie pomimo losowości, lecz - o czym była mowa w Części 6 - dlatego, że losowość stanowi jeden ze środków służących wypełnieniu Jego woli.

Uczeni nie są zgodni, które z powyższych ujęć jest najbardziej przekonujące. Teizm otwarty przeczy twierdzeniu klasycznej teologii chrześcijańskiej, że Boża wszechwiedza obejmuje także wiedzę o przyszłości. Zważywszy na stopień akceptacji tej klasycznej tezy, jej odrzucenie wymagałoby sformułowania bardzo mocnego argumentu. W moim przekonaniu argument na rzecz teizmu otwartego nie jest jednak zbyt mocny. Koncepcja prostej przedwiedzy afirmuje wolną wolę (a co za tym idzie - losowość), ale nie dostarcza klarownego ujęcia związku między Bożą przedwiedzą a tą wolnością. Molinizm krytykowano na różne sposoby. Zwracano szczególną uwagę na problem, dlaczego Bóg, z góry znając wolne wybory stworzonych istot, stworzył upadłe dusze. 
Skłaniam się ku molinizmowi, ponieważ oferuje przekonujące ujęcie tego, jak można pogodzić Bożą przedwiedzę z losowością ontologiczną. Wydaje się również, że Boska wszechwiedza powinna obejmować wiedzę pośrednią i że Bóg posłużyłby się nią, dokonując stworzenia. Problem ten jest daleki od rozwiązania, ale omówione podejścia pokazują, że da się sformułować przekonujące argumenty na rzecz pogodzenia losowości i Bożej przedwiedzy.

\section{Przyczynowość}

Oden pisze, że wszechobecność Boga oznacza (między innymi), że Bóg jest obecny w każdym akcie przyczynowym. Tradycyjnie myśliciele chrześcijańscy utożsamiają Boga z pierwszą przyczyną wszelkich aktów, ale obserwowane zdarzenia mogą mieć przyczyny wtórne. Fizycy, którzy akceptują kopenhaską interpretację mechaniki kwantowej, zwykle łączą nieokreśloność kwantową z brakiem przyczynowości. Wielu myślicieli chrześcijańskich jest temu przeciwnych. Na przykład John Byl tak argumentuje przeciwko idei kwantowej losowości:

W rzeczy samej, podstawowa zasada racjonalnych dociekań głosi, że wszystko ma rację dostateczną. Zasada Racji Dostatecznej pociąga za sobą Zasadę Przyczynowości, która potwierdza, że każde zdarzenie ma wystarczającą przyczynę. Twierdzenie, że wybór kwantowy dokonywany jest przypadkowo, jest równoznaczne ze stwierdzeniem, że wybór ten dokonywany i wywoływany jest przez „nic”. Jest to sprzeczne z Zasadą Racji Dostatecznej. Uznanie, że jakieś zdarzenie nie ma przyczyny, oznacza porzucenie nauki i odwołanie się do magii, w tym wypadku do magii, za którą nie stoi nawet żaden magik. ${ }^{52}$

Robert Kane odróżnia natomiast zasadę racji dostatecznej od aksjomatu racji dostatecznej. Ta pierwsza mówi, że jeśli $\mathrm{p}$, to istnieje racja dostateczna dla $\mathrm{p}$. Aksjomat racji dostatecznej jest zaś jej konwersem i mówi, że jeżeli istnieje racja dostateczna dla $\mathrm{p}$, to $\mathrm{p}$. Kane pisze:

[...] będzie logicznie możliwe, że zajdzie coś (na przykład losowe zdarzenie), co nie ma racji dostatecznej lub wyjaśnienia swojego zaistnienia.

\footnotetext{
${ }^{52}$ ByL, „Indeterminacy...”, s. 102-103.
} 
[...] Możemy powiedzieć, że aksjomat racji dostatecznej definiuje dostateczność racji dostatecznej. Nie wydaje się natomiast, by z definicji racji dostatecznej dało się wyprowadzić tezę, że taką rację musi mieć wszystko, co istnieje, a tego wymaga zasada racji dostatecznej. ${ }^{53}$

Byl zdaje się wynosić zasadę racji dostatecznej na poziom aksjomatu. Zasada ta zakłada determinizm, a więc oparty na niej argument przeciwko istnieniu przypadku z góry przesądza sprawę.

Rozważmy następujący eksperyment myślowy. Samiec niedźwiedzia przemierza las w okresie godowym, by znaleźć partnerkę. Jeleń następuje na patyk, wydając trzask. Niedźwiedź zatrzymuje się, nasłuchuje i rusza dalej. W momencie tego zawahania jego sperma uległa przepływowi, tak że materiał genetyczny przekazany przez niego później jest inny niż byłby, gdyby nie to zdarzenie. Przy wyjaśnieniu składu genetycznego potomstwa tego niedźwiedzia patyk nie pojawiłby się jako przyczyna. Przypuśćmy teraz, że jeleń postawił nogę kilka centymetrów dalej i nie nastąpił na patyk. To nie-zdarzenie również nie pojawiłoby się w wyjaśnieniu przyczynowym. Innymi słowy, można sformułować wyjaśnienie przyczynowe dla składu genetycznego potomstwa, ale mimo to nieokreśloność i tak byłaby obecna. W rzeczywistości wiele takich kontrfaktycznych sytuacji może zmienić DNA potomstwa, ale żadne nie pojawiłoby się w wyjaśnieniu przyczynowym. Inny przykład: powiew wiatru mógł spowodować, że pszczoła w ogrodzie Mendla lekko się poruszyła. Zapylone ziarna na jej grzebiecie byłyby inne i groch otrzymałby inny materiał genetyczny niż wówczas, gdyby wiatr nie zawiał.

Rozważając sytuacje kontrfaktyczne, możemy dostrzec, że przyczynowość probabilistyczna może istnieć, nie wykluczając obecności Boga w łańcuchu przyczynowym.

\section{Uwagi końcowe}

Jak istnienie losowości ontologicznej w świecie fizycznym może wpłynąć na to, jak postrzegamy Boga?

\footnotetext{
${ }^{53}$ Robert Kane, „Principles of Reason”, Erkenntnis 1986, vol. 24, s. 117.
} 
Po pierwsze, apostoł Paweł pisze:

O głębokości bogactw, mądrości i wiedzy Boga.

Jakże niezbadane są Jego wyroki i nie do wyśledzenia jego drogi! (Rz 11:33 [BT])

Losowość można postrzegać jako subtelny wyraz mądrości Bożej — liczby składają się z bitów, których nie da się wygenerować przez żaden proces algorytmiczny; ogromnie złożone układy mają składniki, które działają niezależnie według własnych praw, jednak w grupie tworzą prosty porządek; trwałość dynamicznie stabilnych układów polega na ich losowości; władza Boga przejawia się na skrajnie różne sposoby na różnych poziomach, a prawa probabilistyczne określają, jak pośród pozornego nieładu może istnieć porządek. Takie czynniki zwiększają nasze rozumienie słów Pawła i mogą prowadzić do głębszej czci.

Po drugie, jak pisał Kalwin:

Przypuśćmy, że jakiś człowiek trafia między złodziei lub dzikie bestie; uczestniczy w katastrofie morskiej wywołanej przez nagły poryw wiatru; zostaje zabity przez walący się dom lub upadające drzewo. Przypuśćmy, że inny człowiek, błąkający się po pustyni, znajduje pomoc w tarapatach; rzucany przez fale dociera do portu; w cudowny sposób o włos unika śmierci. Cielesny rozum przypisuje wszystkie te zdarzenia, czy to szczęśliwe czy nie, fortunie. Ale wszyscy, których Chrystus uczył, że każdy włos na ich głowie jest policzony [Mt 10:30], dalej szukać będą przyczyny i uznają, że wszystkie zdarzenia rządzone są tajnym planem Boga. ${ }^{54}$

Zaprezentowany w tym artykule pogląd na losowość może wprowadzić pewne niuanse do stanowiska Kalwina. Nie musimy przeciwstawiać „fortuny” Chrystusowi, łącząc ją z „,cielesnym rozumem”. Losowość wskazuje raczej, że przykłady podane przez Kalwina powinniśmy interpretować systematycznie Bóg zarządził, by takie zdarzenia występowały, ale zamiast uznawać, że każde konkretne zdarzenie zachodzi w wyniku woli Boga, dostrzegamy szerszy układ, w którym zdarzenia zachodzą losowo zgodnie z Bożą wolą. Świat indeterministyczny zapewnia arenę, na której Bóg może demonstrować opatrznościową troskę. ${ }^{55}$

\footnotetext{
${ }^{54}$ John CALVIN, Institutes of the Christian Religion, I, XVI, 2.

${ }^{55}$ Więcej na ten temat por. w: Paul EwarT, „The Necessity of Chance: Randomness, Purpose,
} 
Po trzecie, Izaak Newton uznawał, że jego teoria grawitacji wyjaśnia dzieło Boga w fizycznym Wszechświecie. Jednak jego następcy za pomocą tych praw chcieli poprzeć deizm. Powoływanie się na procesy indeterministyczne w celu wyjaśnienia zdarzeń $\mathrm{w}$ świecie fizycznym również może prowadzić do deizmu. Ale nie musi. Zgodnie z myślą Tomasza z Akwinu indeterminizm może wzmocnić szacunek dla wolności, jaką Bóg nadał stworzeniu, oraz pomóc dostrzec opatrznościową troskę Boga.

I wreszcie, losowość daje lepsze podstawy do sformułowania subtelniejszej teodycei niż determinizm. Ta kwestia przekracza jednak ramy tego artykułu.

\section{Podziękowania}

Chciałbym podziękować Kennethowi Constantine'owi, Russellowi Howellowi, Rogerowi Konyndykowi i Mary Vanden Berg za komentarze do pierwszej wersji tego artykułu. Za bardzo pomocne komentarze jestem wdzięczny również trzem anonimowym recenzentom.

James Bradley

\section{Randomness and God's Nature}

\section{Summary}

Observations of apparently random phenomena are commonplace in science. However, randomness and Christian belief are often seen as incompatible, both by naturalists and by theists. This article argues that the scientific concept of randomness and the historic Christian understanding of God's nature are compatible. It argues that the existence of randomness cannot be settled scientifically; nevertheless, it clarifies randomness as a mathematical concept, argues that it provides a plausible interpretation of scientific data, and argues that its existence is consistent with God's nature as it is commonly understood by systematic theologians.

Keywords: ontological randomness, epistemic randomness, God's attributes, omnipotence, omniscience, omnipresence, purpose, sovereignty, foreknowledge, causality.

and the Sovereignty of God”, Science and Christian Belief 2009, vol. 21, no. 2. 
Slowa kluczowe: losowość ontologiczna, losowość epistemiczna, atrybuty Boga, wszechmoc, wszechwiedza, wszechobecność, cel, władza, przedwiedza, przyczynowość. 